\title{
GIS Based Impact Assessment of "Bajaj Water Conservation Project" (BWCP) in the context of Status of Ground Water Level through Well Inventory in the Project Area, Aurangabad, Maharashtra-India- A Case Study
}

\author{
B. S. Mehta*, Dnyaneshwar Talekar ${ }^{* *}$ \& Archana Gentyal ${ }^{* * *}$ \\ GIS-MIS, Jankidevi Bajaj Gram Vikas Sanstha (JBGVS), Viveknagar, Akurdi, Pune-Maharshtra-India-411035 \\ DOI: 10.29322/IJSRP.11.08.2021.p11667 \\ http://dx.doi.org/10.29322/IJSRP.11.08.2021.p11667
}

\begin{abstract}
Groundwater is one of the most important natural resources of the region which is the principal source of drinking water as well as for the agricultural activities for most of the villages in the study district. Repeated droughts are the common phenomenon of this area. This case study is carried out to determine the impact on ground water level due to various water conservation activities are being done in 110 villages of Marathwada region in Aurangabad district, Maharashtra, India by the CSR of BAJAJ group of companies since 2017. The well inventory of around 1250 dug wells for the year 2018, 2019 and 2020 have been used to estimate the water level status in pre and post monsoon season on the landscape with the help of geo-spatial analysis tool of Arc GIS. Year 2018 is considered the base year to compare the impact on two consecutive years (2019 \& 2020). The measurement of water level of each observation well has been taken manually using the measurement tape to determine the water level from the ground for each season to compute the groundwater surface elevation from 2018 to 2020. The spatial interpolation technique "Empirical Bayesian Kriging" of Arc GIS has been used to estimate unknown depths to water table in an aquifer where the water level data has not been observed. The results are indicating the overall rising trend of water level from 2018 to 2020, it is from maximum up to 5 meter in 2018 to 11 meter in 2020 in the month of May (pre-monsoon). Further, it is estimated for the month of November (post monsoon) ranging from maximum up to 9 meter in 2018 to 27 meter in 2020. The fluctuation in the water level has also been observed due to the rainfall trend in the area which indicates that the artificial recharge water harvesting structures has been built are performing well and impacting the ground water level exponentially in the drought prone area of Marathwada region of Maharashtra. Resulted now the people of the 110 villages are getting sufficient water from the dug wells for their domestic as well as for agricultural purposes in the vicinity and not dependent on the water tankers to meet their water needs as earlier.
\end{abstract}

Index Terms- Bajaj, GIS, Ground Water, Impact Assessment, Kriging, Water Conservation, Well Inventory.

\section{INTRODUCTION}

A urangabad district mainly situated in the Godavari river basin and partly in the Tapti river basin of the state of Maharashtra in Marathwada region, India between North Latitude $19^{\circ} 15^{\prime}$ and $20^{\circ} 40$, and East Longitude $74^{\circ} 37^{\prime}$ and $75^{\circ} 52^{\prime}$ (Fig. 1). The bordering districts are Nasik (on west), Jalgaon (on north), Jalna (on east) and Ahmednagar (on south). Geologically the district lies on Deccan Plateau which has two distinct layers; the upper layer consists of vesicular and amygdule zeolitic basalt, while lower layer consists of massive basalt.

The climate of the district is characterized by a hot summer and a general dryness throughout the year except during the southwest monsoon season, which is from June to September while October and November constitute the post monsoon season. December is the coldest month with the mean maximum temperature of $28.9^{\circ} \mathrm{C}$, while the mean minimum temperature is $10.3^{\circ} \mathrm{C}$. May is the hottest month with the mean maximum temperature of $39.8^{\circ} \mathrm{C}$ and the mean minimum temperature of $24.6^{\circ} \mathrm{C}$. (Report of CGWB, Govt of India, 2009).

Groundwater is one of the most important natural resources of the region which is the principal source of drinking water for most of the villages in the district. Ground water systems are very dynamic and adjusting continuously to short term and long-term changes in rainfall, temperature, ground water extraction, land use etc. As per the Agro-climatic Zones, Aurangabad district falls under western drought prone area and Central plateau assured rainfall zone. Southern part of the district falls under Western drought prone area characterized by low and unpredictable rainfall of 500 to $700 \mathrm{~mm} / \mathrm{year}$ with the number of rainy days varying between 40 to 45 days (in which our study area is located). Common dry spells last for 2 to 10 weeks. Delayed onset and early cessation of S-W monsoon is very common. Rest of the district falls in Central Plateau assured rainfall zone and is characterized by rainfall of 700 to $900 \mathrm{~mm} / \mathrm{year}$. 
The normal rainfall of the district is $734.1 \mathrm{~mm}$ spread over 54 rainy days in normal conditions. (Aquifer Maps and Ground Water management Plan, Aurangabad District-2019 by CGWB). The tahsil wise historical rainfall data for last 16 years is given below in table 1.

Table 1: Tahsil Wise Annual Rainfall of Aurangabad District, Maharashtra (2002 - 2017)

\begin{tabular}{|c|c|c|c|c|c|c|c|c|c|c|c|c|c|c|c|c|c|c|}
\hline Tahsil & $\begin{array}{c}\text { Normal } \\
\text { RF }\end{array}$ & 2002 & 2003 & 2004 & 2005 & 2006 & 2007 & 2008 & 2009 & 2010 & 2011 & 2012 & 2013 & 2014 & 2015 & 2016 & 2017 & $\begin{array}{c}\text { Average } \\
\text { RF }\end{array}$ \\
\hline Aurangabad & 737.6 & 629 & 792.7 & 711.6 & 677.2 & 937.4 & 552.4 & 746.6 & 731.7 & 802.9 & 668.8 & 406.6 & 724.7 & 526.6 & 716.8 & 735.9 & 663.3 & 689.0 \\
\hline Paithare & 634.3 & 586.9 & 578.6 & 787.6 & 512.3 & 873.2 & 545.1 & 533.5 & 539.2 & 721.2 & 491.3 & 349 & 591.8 & 420.7 & 408.1 & 549.4 & 480 & 560.5 \\
\hline Gangapur & 627.9 & 440.3 & 203.3 & 657.4 & 499.9 & 918.2 & 619.8 & 626 & 621.8 & 839.9 & 535.4 & 239 & 513.1 & 408.7 & 459.2 & 446.9 & 518.9 & 534.2 \\
\hline Vaijary & 523 & 405 & 255 & 484.4 & 445.8 & 843.1 & 538 & 614.7 & 635.6 & 868.5 & 523.6 & 388.6 & 500.6 & 414.8 & 457.3 & 569 & 638.6 & 536.4 \\
\hline Bannod & 657.9 & 594.7 & 440.8 & 496.2 & 506.4 & 971.1 & 537.3 & 672.6 & 755.8 & 967.1 & 694.6 & 350.8 & 769 & 626.3 & 713.6 & 638.1 & 580.5 & 645.0 \\
\hline Ehuldabad & 778.5 & 932.9 & 761.3 & 717.9 & 481.1 & 963.8 & 562.9 & 841.4 & 670.1 & 1136 & 580.5 & 371.8 & 594.6 & 470.4 & 614.1 & 585 & 593.3 & 679.8 \\
\hline Sillod & 706.1 & 758.6 & 648.9 & 624.7 & 482.2 & 1085.6 & 644.5 & 501.8 & 750.8 & 961.7 & 709.6 & 441.4 & 821.6 & 711.9 & 746 & 699.4 & 629.4 & 701.1 \\
\hline Soxgapm & 775.9 & 814.2 & 1035.3 & 694.6 & 651.2 & 1010.4 & 682.9 & 669.1 & 872.5 & 917.1 & 644 & 482.6 & 936.9 & 773.7 & 608.2 & 745.7 & 436.1 & 748.4 \\
\hline Phulambari. & 566.2 & 497 & 603.2 & 445.4 & 494.2 & 681.8 & 627.9 & 658.7 & 650.1 & 773.4 & 454.7 & 344.1 & 658.5 & 594.8 & 785.8 & 646.2 & 556.5 & 592.0 \\
\hline
\end{tabular}

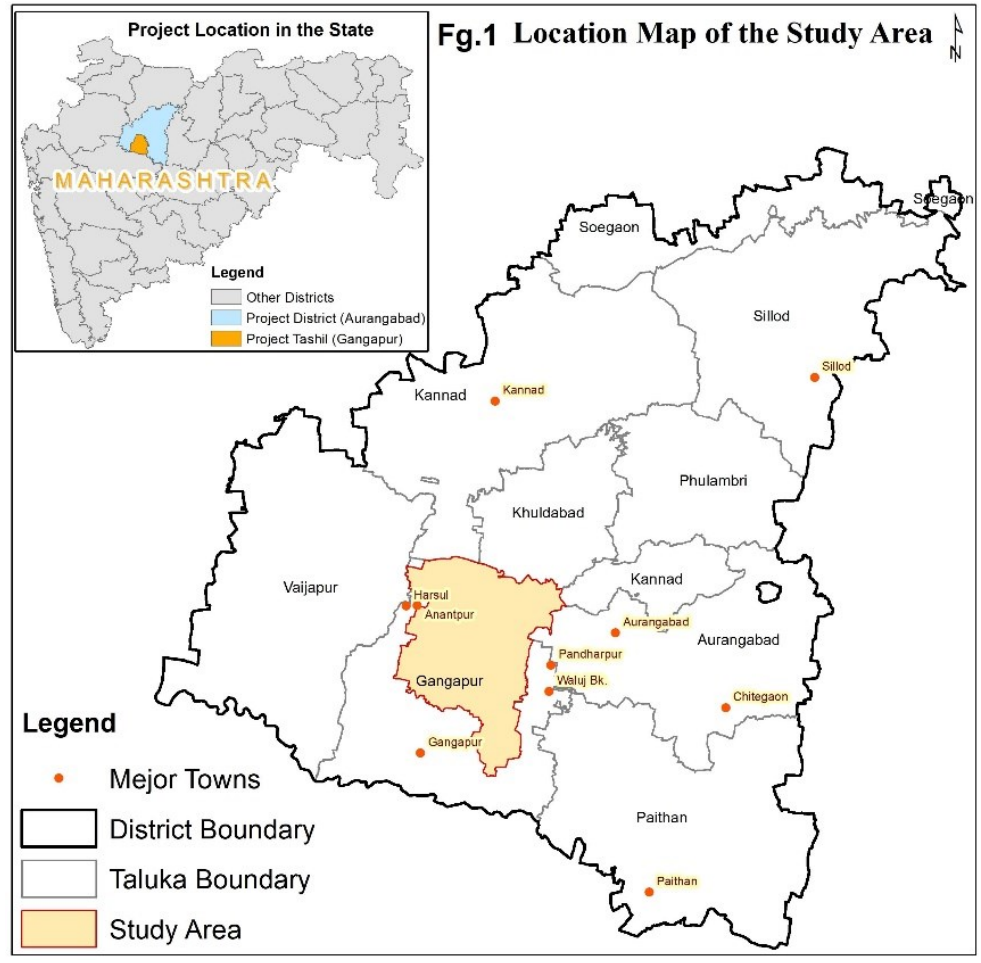

Since the BAJAJ is committed to serve the community in their critical common needs, the rainfall pattern along with other climatic parameters of the district has been analyzed at taluka level, and it reveals that the Gangapur and Paithan situated in the southern part of the district has been frequently affected by droughts and received least average rainfall among all talukas between 2002-2012, in addition to that we have conducted a field survey in 2016 to check the facts on the ground and we found most of the villages in Gangapur and Paithan taluka were dependent on water tankers to meet their water needs. Thus, Jankidevi Bajaj Gram Vikas Sanstha (JBGVS) has identified the Gangapur and Paithan taluka as priority area for water conservation activities to be undertaken to address this issue of water crises with best possible resources available, hence in 2017-18 we have launched "Bajaj Water Conservation Project" (BWCP) (Fig.1) in the area. Since then, the various water conservation activities are being implemented by the JBGVS and with the help of other partner organizations (AFARM, DSC, BIAF, AFPRO, and BISLD) in the Gangapur and Paithan taluka of the district. To evaluate the impact in the ground water level due to the various water conservation activities over the time of project implementation (2017-2020) the GIS based study is being conducted. 


\section{METHODOLOGY}

The following methodology has been adopted to conduct a study to evaluate the impact on ground water level by monitoring the pre and post scenario of water level in the selected dug wells during the study period (2018-2020).

1. Selection of Observation Wells: Decisions made about the number and locations of observation wells are crucial to any waterlevel data collection program. Ideally, the wells chosen for an observation well network will provide data representative of various topographic, geologic, climatic, and land-use environments. (Charles J. Taylor et.al, Denver, Colorado, 2001) Keeping in view to take representative samples for the study area we have geo-tagged almost all existing dug wells (10285) spreading across 110 villages with the help of high resolution google earth imagery, and subsequently it has been cross verified at village

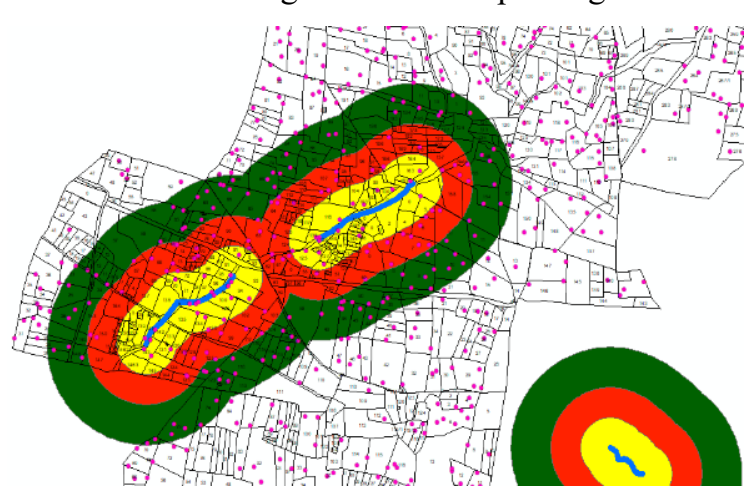
level by the ground staff. Then we have created a buffer of $1 \mathrm{~km}$ (as shown in the figure at left side) for the planned water harvesting structures such as NDW (nala deepening and widening), CNB (cement nala bund) and PT (percolation tanks) and overlaid on the layer of dug wells (10285) to make sure the observation wells must have been selected within $1 \mathrm{~km}$ radius of the water harvesting structure to be built. By following this criterion, we have chosen 1250 dug wells out of 10285 geo-tagged after verifying on the ground spreading across all over the study villages (110) (Fig.2) Then we have done the unique coding for each observation well and done the permanent marking on it using the waterproof paint to eliminate the possible error while collecting the data of each observation well during the study period which helped us to maintain the uniformity and integrity of the data. The selected observation wells are proving the representative data for various topography and land use patterns exists in the area since 2018 to till date and we will continue to record the data for next few years to study the long-term impact.

2. Water Level Measurements: As our objective of the study was to detect impact on the ground water level for pre-monsoon (May) and post-monsoon (November) due to various water conservation activities has been implemented over the period. We have taken the measurement of each observation well manually using the measurement tape to determine the water level from the ground for each season to compute the groundwater surface elevation from 2018 to 2020 .

The following criterion has been followed for water level measurements:

a. Total depth of each observation well from the ground level to bottom measured using the measurement tape and recorded.

b. Total depth of water level from the ground measured using the measurement tape and recorded.

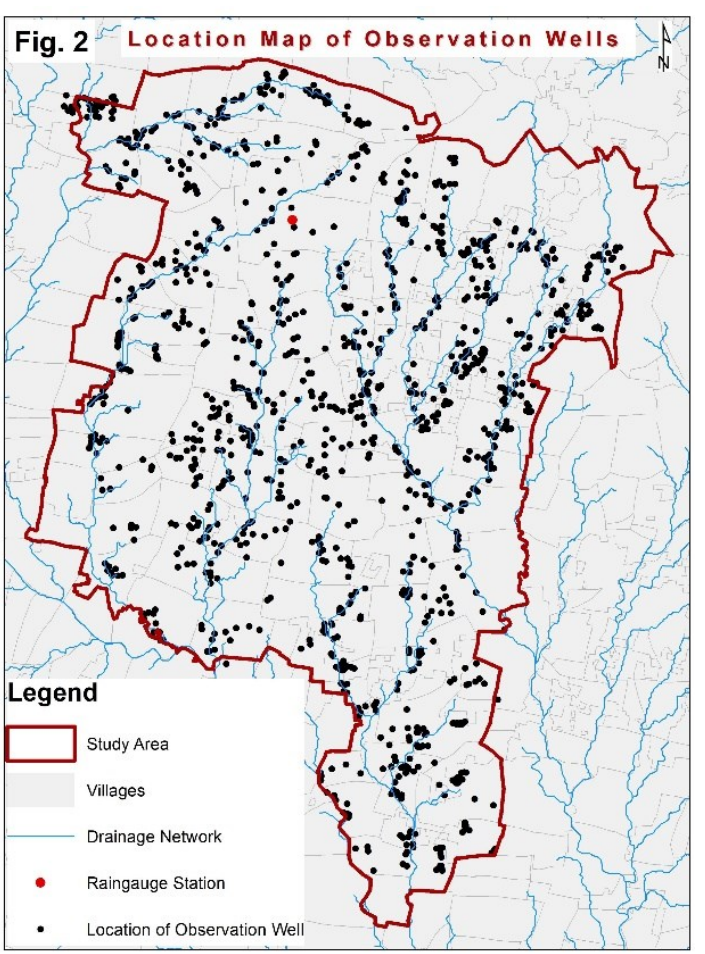

c. Then we derived the water level from the bottom of the well by applying this equation for each season uniformly Total Depth of the well - Water Level from the ground = Water Level of the Well from the bottom. 
d. We have fixed the date to take the measurements for each observation for each month (May and November).

e. We have taken care about the water has not been pumped out from the observation well before taking the measurement on the day by requesting to the farmer/owner of the well in a day before.

3. Quality Assurance of the Data: Good quality-assurance practices help to maintain the accuracy and precision of water-level measurements, ensure that observation wells reflect conditions in the aquifer being monitored, and provide data that can be relied upon for many intended uses. Therefore, field and office practices that will provide the needed levels of quality assurance for waterlevel data should be carefully thought out and consistently employed. (Charles J. Taylor et.al Denver,

Water Level is Being Measured through Measurement Tape

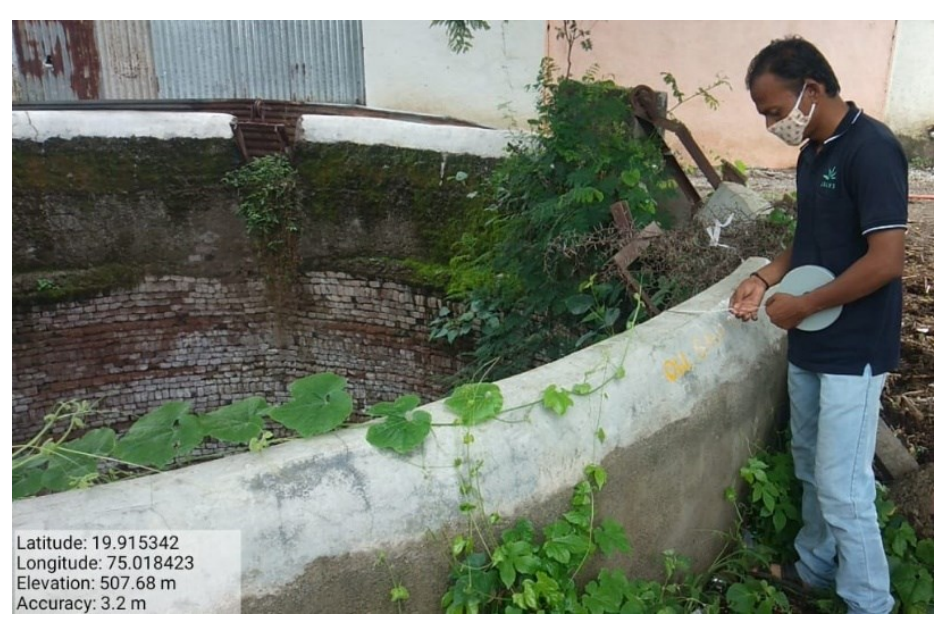
Colorado, 2001). Keeping in view of this we have strictly followed some important field practices to get quality of water level data which includes the geo-tagging of each observation well with 3-to-5 meter locational accuracy, unique coding for each well, periodic inspection of the well, measurement has taken on the fixed date, water has not get pumped out on the day of observation, cross validation of the ground data with the help of GIS tools, dropped the suspicious data while doing final analysis etc.

4. Data Analysis: Water level data collected for the study period has been systematically stored in excel format with the geographic coordinates (Latitude/Longitude) and compiled for pre and post monsoon season. Created a vector layer based on the Lat/Long value having all the required attributes such as well depth, water level from the bottom for each month to run the advanced analysis on GIS platform. To analyze and create a groundwater surface elevation map for pre and post monsoon season the following statistical module have been used on GIS platform.

Kriging Interpolation: One of the most widely used computer programs for spatial interpolation in this and other fields is the Geostatistical Software Library (GSLIB), developed at Stanford University (Deutsch and Journel, 1992). This library contains functionality for spatial interpolation using the Kriging technique pioneered by the South African statistician and mining engineer, Danie G. Krige. Kriging is used by many groundwater researchers when attempting to interpolate spatial data, as it provides both spatial estimation and a map of the uncertainty associated with the interpolated data. Interpolation is the process of obtaining a value for a variable of interest at a location where data has not been observed, using data from locations where data has been collected. Kumar (2006) used Kriging interpolation to estimate unknown depths to water table in an aquifer in Rajasthan, India and found that kriged groundwater levels satisfactorily matched the observed groundwater levels.

\section{RESULTS AND DISCUSSION}

We have been used the 1250 dug wells spreading across 110 villages of the study area for the water level analysis. Each well contained the data of water level for the month of May and November from 2018 to 2020, the data of 2018 is considered as a base year to compare the impact on water level across the landscape. The location of these wells shown earlier in Fig.2. The water level estimation has been computed through statistical interpolation technique on GIS platform based on the water level data of the observation wells collected in the month of May and November for the study years $(2018,2019 \& 2020)$.

1. Pre-Monsoon Level Estimation: Status of pre-monsoon (May) water level is the most important indicator to measure the sustainability of the ground water resources of the area. Based on the statistical interpolation on GIS platform, the water level estimation maps for the year 2018, 2019 and 2020 has been prepared on the same scale and presented below (Fig.3) and the maps are self-explanatory. The maps below depict the overall rising trend of water level from 2018 to 2020 . The lightest color on the map indicates the lowest water level and darkest color indicate the highest water level on the landscape. To get the more clarity on the impact on water level of the study area we are presenting here the results of estimation done in the table 2 given below: 


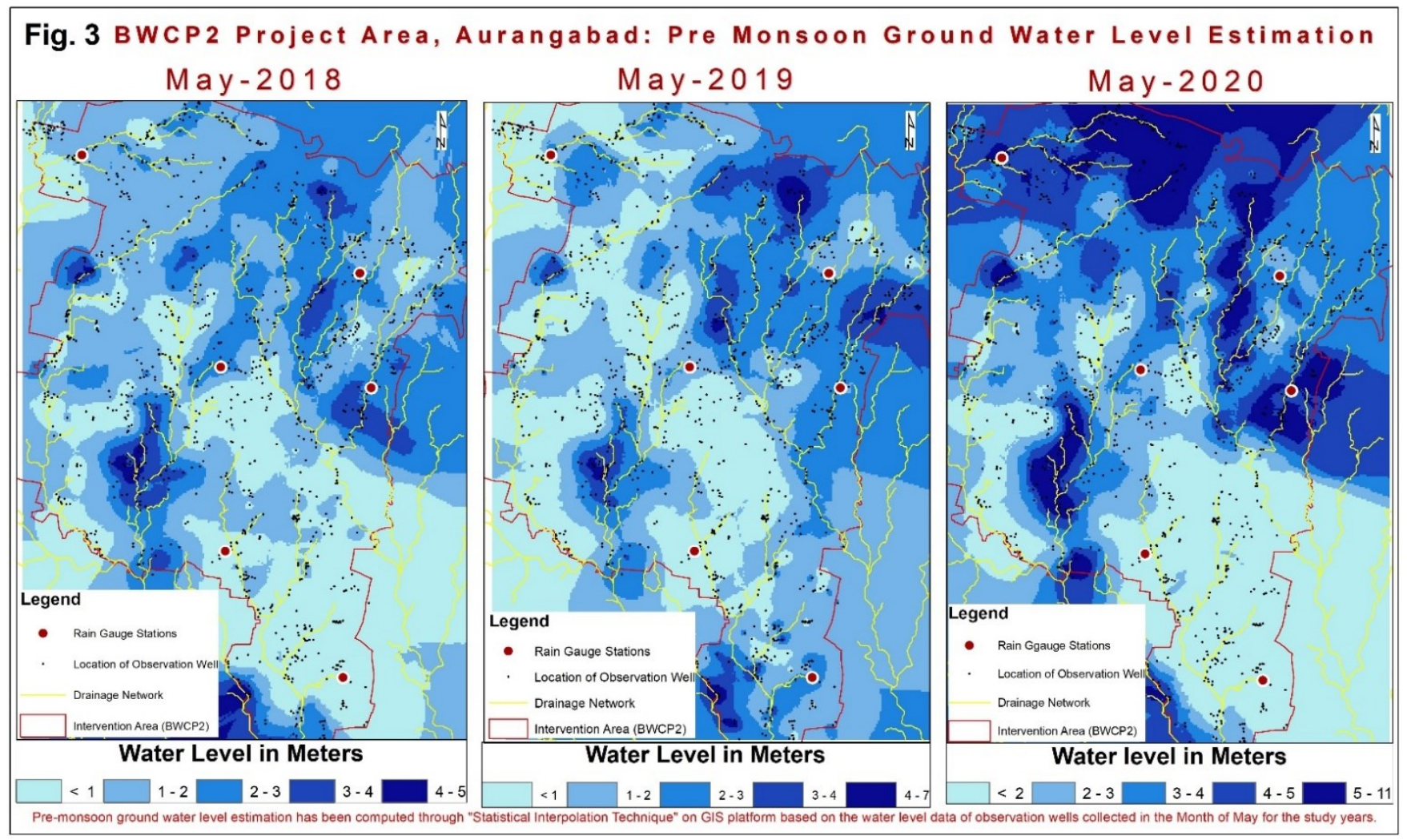

Table 2: Pre-Monsoon (May) Water Level Estimation

\section{Pre-Monsoon Water Level Estimation}

\begin{tabular}{|c|c|c|c|c|c|c|c|c|}
\hline \multicolumn{3}{|l|}{ May 2018} & \multicolumn{3}{|l|}{ May 2019} & \multicolumn{3}{|l|}{ May 2020} \\
\hline $\begin{array}{l}\text { Water } \\
\text { Level in } \\
\text { Meters }\end{array}$ & $\begin{array}{l}\text { Area in } \\
\mathrm{Ha}\end{array}$ & $\begin{array}{l}\text { Area in } \\
\%\end{array}$ & $\begin{array}{l}\text { Water } \\
\text { Level in } \\
\text { Meters }\end{array}$ & $\begin{array}{l}\text { Area in } \\
\text { Ha }\end{array}$ & $\begin{array}{l}\text { Area in } \\
\%\end{array}$ & $\begin{array}{l}\text { Water } \\
\text { Level in } \\
\text { Meters }\end{array}$ & $\begin{array}{l}\text { Area in } \\
\mathrm{Ha}\end{array}$ & $\begin{array}{l}\text { Area in } \\
\%\end{array}$ \\
\hline$<1$ & 31905 & 34.83 & $<1$ & 22288 & 24.33 & $<2$ & 28354 & 30.95 \\
\hline 1 to 2 & 23844 & 26.03 & 1 to 2 & 23311 & 25.44 & 2 to 3 & 29199 & 31.87 \\
\hline 2 to 3 & 19508 & 21.29 & 2 to 3 & 22616 & 24.69 & 3 to 4 & 18587 & 20.29 \\
\hline 3 to 4 & 11040 & 12.05 & 3 to 4 & 18160 & 19.82 & 4 to 5 & 13484 & 14.72 \\
\hline 4 to 5 & 5316 & 5.80 & 4 to 7 & 5238 & 5.72 & 5 to 11 & 1990 & 2.17 \\
\hline Total & $91614^{*}$ & & Total & $91614^{*}$ & & Total & $91614^{*}$ & \\
\hline
\end{tabular}

*Area has been calculated based on the cell size of the map using the GIS tool and it may not tally with the area reported by revenue department or any other agency.

According to the data presented in the table 1 reveals that the water level is estimated in the month of May is ranging from maximum up to 5 meter in 2018 to 11 meter in 2020. The water level estimation has been computed for the study area of around 91600 ha. covering 110 project villages and out of this $\mathbf{5 . 8} \%$ area comes under the water level of 4-to-5-meter range in the year of 2018 whereas it has been increased in 2020 to $14.72 \%$ of the area. The data also reveals that the water level ranges has been gradually increased in the consecutive years from 4 to 5 meters covering an area of $5.8 \%$ in $\mathbf{2 0 1 8}$ to $\mathbf{4}$ to $\mathbf{7}$ meter covering an area of $5.72 \%$ in 2019 and further 5 to 11 meter covering an area of $2.17 \%$ in 2020. It is important to mention here that there should not be any dispute about the reflection of the rainfall in the water level of the area, more rain means higher water level if it is percolate through the aquifer to recharge the ground water. The five rain gauge stations situated in the study area (Fig.3) has recorded an average rainfall of $\mathbf{2 9 2}$, 396 and $597 \mathbf{~ m m}$ respectively in 2018, 2019 and 2020, which can be easily correlated with the water estimation data for the respective years.

\section{Post Monsoon Water Level Estimation:}


The post monsoon scenario of the water level in the study area has raised drastically if we compared and analyzed the data of 2018 and 2020. The data presented in the table 3 below reveals that the water level is estimated in the month of November is ranging from maximum up to 9 meter in 2018 to 27 meter in 2020 which shows the impact of various rainwater harvesting structures created in the area.

Table 3: Post-Monsoon (November) Water Level Estimation

\begin{tabular}{|c|c|c|c|c|c|c|c|c|}
\hline \multicolumn{9}{|c|}{ Post-Monsoon Water Level Estimation } \\
\hline \multicolumn{3}{|c|}{ November 2018} & \multicolumn{3}{|c|}{ November 2019} & \multicolumn{3}{|c|}{ November 2020} \\
\hline $\begin{array}{l}\text { Water } \\
\text { Level in } \\
\text { Meters }\end{array}$ & $\begin{array}{l}\text { Area in } \\
\mathrm{Ha}\end{array}$ & $\begin{array}{l}\text { Area in } \\
\%\end{array}$ & $\begin{array}{l}\text { Water } \\
\text { Level in } \\
\text { Meters }\end{array}$ & $\begin{array}{l}\text { Area in } \\
\mathrm{Ha}\end{array}$ & $\begin{array}{l}\text { Area in } \\
\%\end{array}$ & $\begin{array}{l}\text { Water } \\
\text { Level in } \\
\text { Meters }\end{array}$ & $\begin{array}{l}\text { Area in } \\
\mathrm{Ha}\end{array}$ & $\begin{array}{l}\text { Area in } \\
\%\end{array}$ \\
\hline$<2$ & 25949 & 28.32 & $<2$ & 37010 & 40.40 & $<9$ & 7797 & 8.51 \\
\hline 2 to 3 & 29356 & 32.04 & 2 to 3 & 21231 & 23.17 & 9 to 12 & 26464 & 28.89 \\
\hline 3 to 4 & 21431 & 23.39 & 3 to 4 & 21374 & 23.33 & 12 to 14 & 21857 & 23.86 \\
\hline 4 to 5 & 11446 & 12.49 & 4 to 5 & 6782 & 7.40 & 14 to 16 & 29900 & 32.64 \\
\hline 5 to 9 & 3431 & 3.75 & 5 to 9 & 5217 & 5.69 & 16 to 27 & 5596 & 6.11 \\
\hline Total & 91614* & & Total & $91614 *$ & & Total & $91614 *$ & \\
\hline
\end{tabular}

* Area has been calculated based on the cell size of the map using the GIS tool and it may not tally with the area reported by revenue department or any other agency.

However, if we compared the estimated ranges in 2018 and 2019 it shows the reasonable increase of the water level in the range of 5 to 9 meter covering an area of $3.75 \%$ in 2018 to $5.69 \%$ in 2019 . Whereas in 2020 the minimum estimated water level range comes below 9 meters, and a major part of the area (32.64\%) comes under the range of 14-to-16 meters water level.

The maps are given below (Fig.4) also depicts the overall rising trend of water level during post monsoon season from 2018 to 2020 and the maps are self-explanatory. The lightest color on the map indicates the lowest water level and darkest color indicate the highest water level on the landscape.

Fig. 4

BWCP 2 Project Area, Aurangabad: Post Monsoon Ground Water Level Estimation

November, 2018

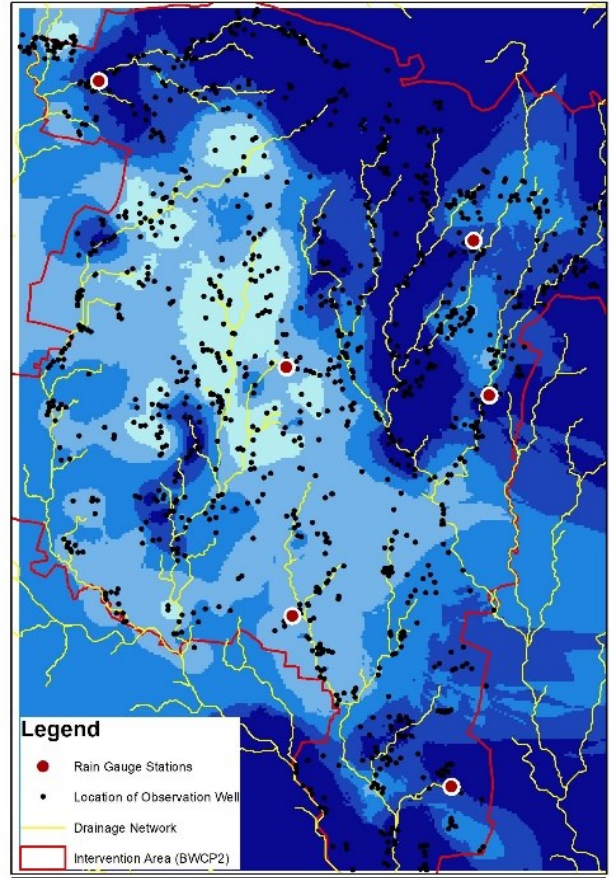

Water Level in Meters
November, 2019

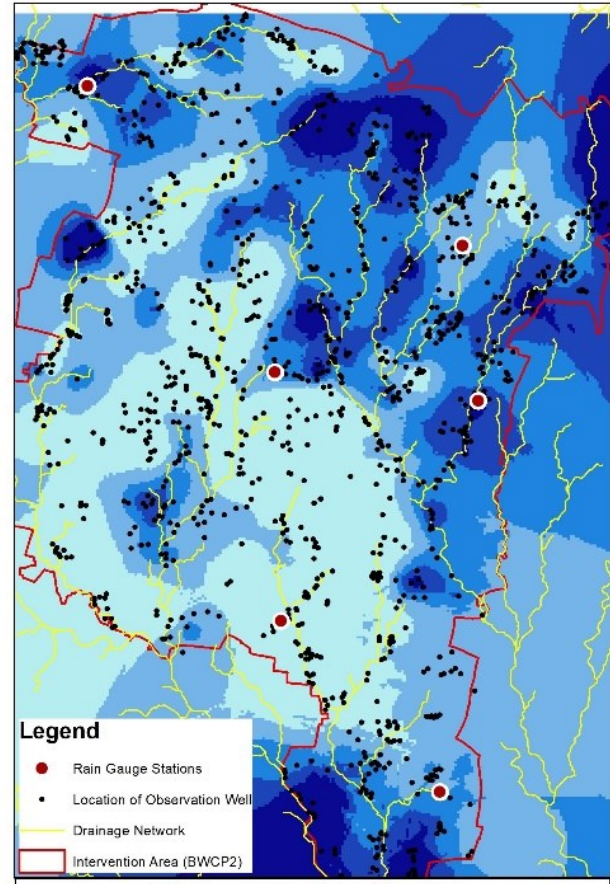

Water Level in Meters
November, 2020

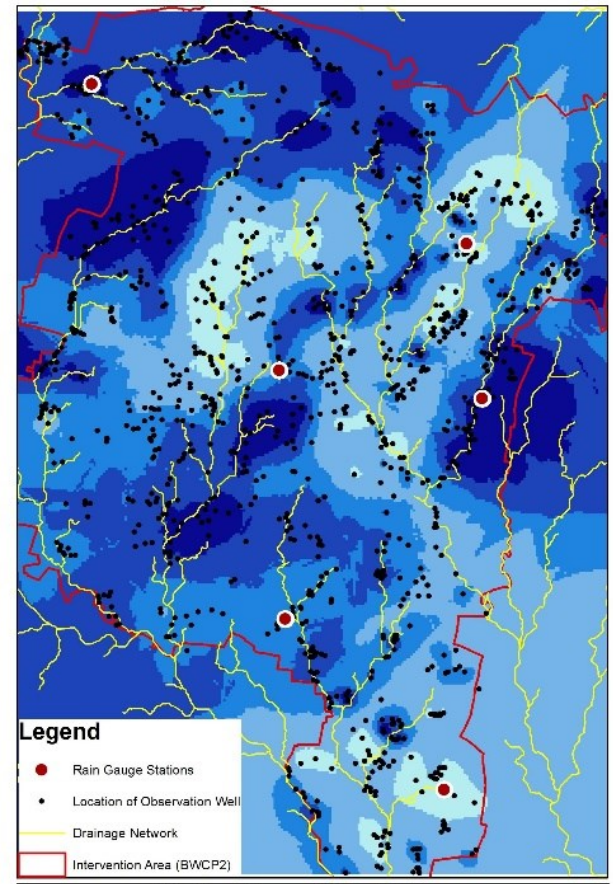

Water Level in Meters

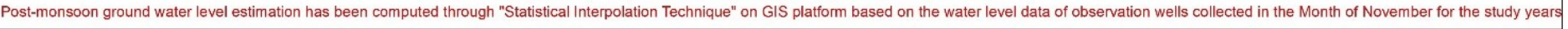




\section{CONCLUSION}

As the Central Ground Water Board (CGWB), Govt of India's, 2013 report indicates that in the major parts of the Aurangabad district has a falling water level trend which includes the southern, southwestern, and central parts occupying almost entire Paithan, Gangapur, Vaijapur and Khuldabad talukas and parts of Kannad and Sillod talukas. And recommended for the future water conservation and artificial recharge structures to be prioritized in these areas such as CCT, nala bunding, gabion structures, vegetative bunds, terracing, check dams, gully plugs, percolation tanks etc.

The Jankidevi Bajaj Gram Vikas Sanstha (JBGVS) has prioritized the suitable water conservation activities as recommended by CGWB in the Gangapur and Paithan tauka and initiated the work in 2017-18, created around 1270 artificial recharge structures till May 2021, out of this 498 NDW (nala deepening and widening), $464 \mathrm{FP}$ (farm pond), $136 \mathrm{CNB}$ (cement nala bund), 126 PTD (percolation tank deepening) and $47 \mathrm{CWG}$ (core wall gabion) have been created (Fig.5). The numbers are reported here are based on the geo-tagged data provided by the zonal team.

The GIS based impact assessment study we have been carried out based on the water level data for 1250 observation wells has been recorded systematically for the base year 2018 and consecutive study years (2019 \& 2020), the study results are very exciting that shows in both during pre-monsoon and post monsoon periods rising trends in water level have been observed in the study area. In the pre-monsoon period, the water level has raised from 5 meter in 2018 to 11 meter in 2020 and in the post monsoon season it is recorded 9 meter in 2018 to 27 meter in 2020. The fluctuation in the water level has also been observed due to the rainfall trend in the area which indicates that the artificial recharge water harvesting structures has been built are performing well and

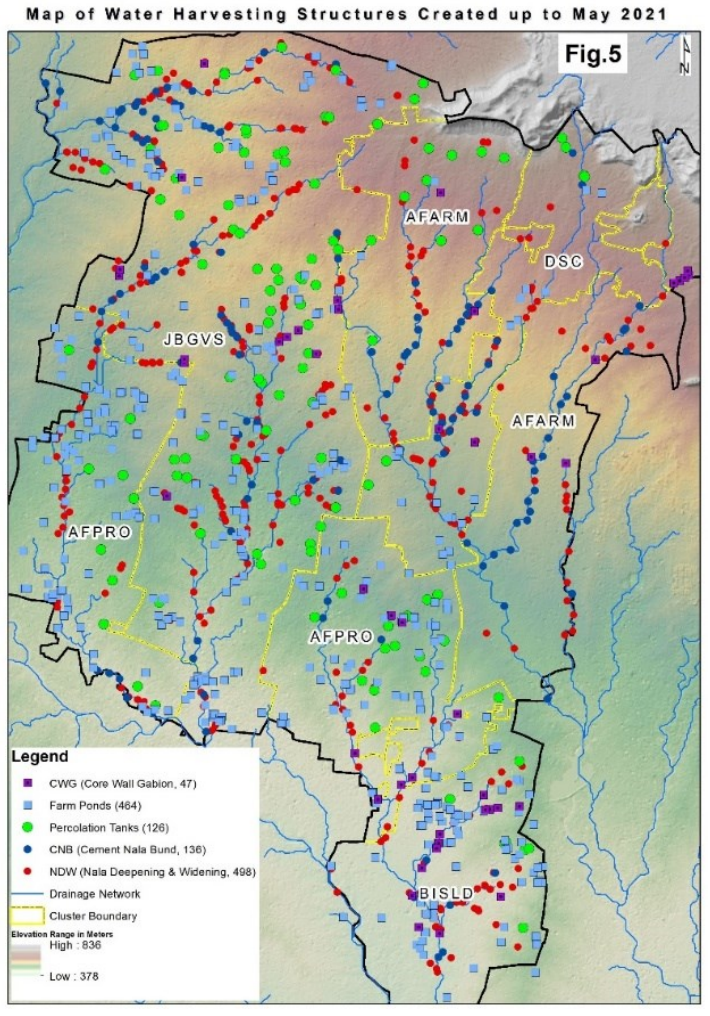
impacting the ground water level exponentially in the drought prone area of Marathwada region of Maharashtra. Resulted now the people of the 110 villages are getting sufficient water from the dug wells for their domestic as well as for agricultural purposes in the vicinity and not dependent on the water tankers to meet their water needs as earlier.

\section{ACKNOWLEDGEMENT}

First and foremost, we would like to express our deep and sincere gratitude to Mr. C. P. Tripathi, Chairman, Jankidevi Bajaj Gram Vikas Sanstha for giving us an opportunity to take up the impact assessment on ground water level of the "Bajaj Water Conservation Project (BWCP)" project area. We are immensely grateful to Mr. Pankaj Ballabh, VP CSR, Bajaj Auto Limited for his comments on an earlier version of the manuscript which helps to improvise the graphical representation. We are also thankful to Mr. A. S. Bhandare, Acting CEO, Jankidevi Bajaj Gram Vikas Sanstha for extending all kinds of administrative support required to complete the study. We are extremely grateful to the "Bajaj Water Conservation Project (BWCP)" implementation team in Aurangabad (Maharashtra) headed by Mr. R. K. Patil and Mr. Y. B. Padole for their continued support while collecting the field data for the study period. We are also very much thankful to the village farmers of the project area who had helped us a lot in well inventory. Finally, we are also very thankful to all our colleagues who directly or indirectly were associated with the project implementation.

\section{REFERENCES}

[1] Charles, J. Taylor and William M. Alley, Ground Water Level Monitoring, and the Importance of Long-Term Water Level Data, U.S. Geological Survey Circular 1217, 2001.

[2] Central Ground Water Board, Department of Water Resources, Govt of India, Aquifer Mapping and Management of Ground Water Resources, Aurangabad District, Maharashtra, India, 2019.

[3] Central Ground Water Board, Department of Water Resources, Govt of India, Ground Water Information Aurangabad District, Maharashtra, India, 2013.

[4] Shekhar, S., Kumar, S., Densmore, A.L. et al. Modelling water levels of northwestern India in response to improved irrigation use efficiency. Sci Rep 10, 13452 (2020). https://doi.org/10.1038/s41598-020-70416-0.

[5] Steven W. Evans, Norman L. jones, Gustavious P. Williams, Daniel P. Ames and E. James Nelson, Groundwater Level Mapping Tool: An opensource web application for assessing groundwater sustainability, ELSEVIER, Environmental Modelling and Software 131 (2020) 104782.

[6] Vijay Kumar and Remaadevi, Kriging of Groundwater Levels- A Case Study, Journal of Spatial Hydrology, Vol. 6, No 1, Spring 2006. 


\section{AUTHORS}

First Author - B. S. Mehta, Ph. D. in Geography, Head, MIS-GIS, Jankidevi Bajaj Gram Vikas Sanstha (JBGVS), Viveknagar, Akurdi, Pune. Email: bsmehta.gis@gmail.com, Mo: +91 8454945994

Second Author - Dnyaneshwar Talekar, M.Tech, Soil and Water Conservation Engineering, Officer GIS, Jankidevi Bajaj Gram Vikas Sanstha (JBGVS), Viveknagar, Akurdi, Pune. Email: dnyanesh.talekar@jbgvs.org.in.

Third Author - Archana Gentyal, M.A. Geography and Diploma in GIS and Remote Sensing, Assistant Officer GIS, Jankidevi Bajaj Gram Vikas Sanstha (JBGVS), Viveknagar, Akurdi, Pune. Email: archanag@jbgvs.org.in. 